\title{
Research on the Opium War and Its Influence from the Perspective of Confrontation between Chinese and Western Culture
}

\author{
Bincheng Mao
}

The King's Academy, Sunnyvale, CA 95054, United States of America

Keywords: Opium War, Culture confrontation, Culture conflict

\begin{abstract}
The struggle between Chinese and Western culture originated in the late Qing Dynasty, and the Opium War was the key point. From the perspective of confrontation between Chinese and western culture, this paper analyzed the origins of the opium war, including the conflict of Chinese sense and world awareness, the conflict of backward technology and advanced science and the conflict of dictatorial system and democratic system. At the same time, the Opium War was an epoch-making event, which makes Chinese culture form the world awareness, science thought and democracy concept.
\end{abstract}

\section{Outline of the Opium War}

From 1870s to the nineteenth Century, the United Kingdom began to import opium to China and increase the amount of opium year by year. The British bourgeoisie tried to dump the Chinese opium to resist trade deficit in an attempt to open the door of the market Chinese. In this process, Britain had a big opium wealth. There is a large amount of outflow of silver in China, and the people are devastated by opium, and their spirit and health are seriously injured. Emperor Daoguang sent imperial envoy Lin Zexu to Guangzhou to prohibit the opium. Lin Zexu destroyed Opium at Humen. The British government as an excuse to Chinese troops, but the Qing government did not in the coastal areas of actively preparing for the lead when the British struck the variable yichujikui. During the war, Chinese people actively fight against Britain. The emergence of Sanyuanli anti British struggle was full of people's determination to fight aggression and strong patriotic sentiment. The first Opium War ended in the defeat of the Qing government, the Qing government was forced to sign the unequal treaty of Shimonoseki. The cause of the Opium War has a close relationship with the conflict between Chinese and Western cultures. Chinese culture has been developing and changing independently in its unique geographical environment, economic environment and social background. In the process of its development and change, though absorbing and merging many academic schools and ideas, and the essence of foreign culture, it has formed a profound system. But it has always maintained its relationship with the source and the same origin, and has maintained its own characteristics for a long time. However, after the Opium War, because of the aggression of the western colonists, the normal process of Chinese social development was interrupted, and China began to fall into a semi colonial and semi feudal society. At the same time, Chinese culture has also changed greatly under the influence of western culture.

\section{Origins of the Opium War from the Perspective of Confrontation between Chinese and Western Culture}

\subsection{Conflict of Chinese Sense and World Awareness}

The Opium War not only represents the conflict and contest between Chinese and British civilizations, but also illustrates the gap between the two countries in social character and military strength. The battle's victory and defeat were actually decided before the war. After the failure of the 1840 Opium War, China was forced to open the country, and the dream of China as the center of the 
world's civilization was broken. The traditional feudal culture has been unable to stop the impact of western culture, the traditional Chinese concept reflects the national consciousness and conceit narrow world regional view, attacked by crushing in front of the conflict of social reality. After that, there have been a number of enlightened people, who published a lot of works and systematically introduced western countries around the world. The Records and Maps of the World by Weiyuan criticized Chinese conservative world view. It believes that the West and Chinese are essentially the same, which should not be called barbarians. Northern nomadic people in western countries are not invaded the Central Plains, but more than Chinese powerful civilization in his opinion, the reason China defeated West, the main reason is not the weapon behind, but domestic politics, so it is a pressing matter of the moment reform of the domestic politics. But the change of advanced thought is only partial, after the Opium War, the Qing government official documents still called West for foreigners, foreign to foreign affairs. Chinese culture still has its own unsurpassed superiority, still own backward wearing a gorgeous coat, making a deceptive argument and practice. It also reflects the inactivity, insensitivity and stubbornness of the inert Chinese cultural centralism has been deeply rooted.

\subsection{Conflict of Backward Technology and Advanced Science}

In ancient China, science and technology had made brilliant achievements, but modern science and technology came into being and spread from the west after the Opium War. In the late Ming and early Qing Dynasty, these western science and technology were introduced to China and communicated with traditional science, forming an opportunity for further development of Chinese society. But because of the more and more stringent policies in Qing Dynasty in the political, it excluded exchanges with other countries and to the exclusion of all foreign exchanges, culture and science, as the western modern science and technology as diabolic tricks and wicked craft. It is characterized by the nature of the world as the center of the world, self-satisfaction. This superior psychology finally led to a completely self-centered closed state at the end of the feudal society in China, and had no knowledge of the great changes in the world at that time. Until the Opium War, because of the influence of intellectuals by traditional Yi Xia concept, and by western capitalist aggression, often show a strong patriotic anti aggression tendency, changes of the time and the level of understanding of foreign trend is still very traditional and old, such as that the British and other capitalist countries but is called poor people shortage of its culture. And moral standards far less than the Celestial Empire, will cause the failure of the Opium War China simply attributed to such damage, and with the national cultural quality system, not too many relationships. The failure of the Opium War, so that the Chinese in a person with breadth of vision in the understanding of the burning shame and humiliation of a basic fact. That is to say, the spear of a big sword is but the artillery of a ship. At the time of the traditional literati. Keep only China doesn't know the world, see to what extent. This is why when Western powers warships with China driving shelling door, Chinese had to restart machetes and spears to resist foreign aggression. At that time, British weapons their level was still in the initial development of firearms is the British era. Qing Dynasty was still in the mix of hot and cold weapon era.

\subsection{Conflict of Dictatorial System and Democratic System}

With the development of science and technology, especially the development of navigation technology, the influx of raw materials, capital, cheap labor and primary products has finally spawned the production of capitalist industry. The emergence of steam engine has declared the coming of the industrial age. The European new rich people will not tolerate the nobles to ride on their backs. This happened in "liberty, equality, fraternity" banner movement, seeking to establish democracy, rule of law and the rights of political system. When the west takes advantage of its political, economic and cultural advantages on the basis of industrialization and expands power to all corners of the world, China is in a passive and unprepared state when establishing a Western centered world order. When the China portal was forced open, western countries have successively entered the industrial revolution of capitalism after the boom, and the China also close the country to 
international intercourse in the peasant economy in the late feudal society. The western capitalist China opened the portal, the main purpose is to free trade in capitalism, will Chinese into a world dominated by the west market, to become the western industrial countries to the dumping of goods and raw materials, and then become the direct possession and domination of the colonies. In order to save the country and the nation, Kang and Liang advocated a person with breadth of vision of the reform. Qing Ting proposed a constitutional monarchy, the establishment of the constitution, the congress system advocated westernization. At the same time or before and after, a large number of pains in the system of westernized intellectuals, respectively, democracy, constitutionalism, civil rights, education, industry, commerce, justice, finance and other issues, put forward a comprehensive reform plan. But the reform is radical and fragile. The reform and maintenance of the advanced western system has been fiercely opposed by the conservatives who adhered to the feudal tradition.

\section{Influence of the Opium War on Chinese Culture}

\subsection{Awakening of World Awareness}

The Chinese regional concept has played a very active role in strengthening people's patriotism, loving home and defending the consciousness of national independence. It has made the Chinese nation in the course of thousands of years of history, and has been one of the greatest nations in the world who are most peaceful and willing to help the people in the surrounding countries. On the other hand, this regional concept has played a negative role in the development of Chinese society. It hinders the further exploration of the knowledge of the world by the Chinese intellectuals, and regards China as the center of the world, the cultural center and the kingdom of heaven. The development of China is seldom considered from the trend of world development and China's position in the world, which makes Chinese people in a relatively closed state. However, after the Opium War, China's advanced intellectuals' regional concept has made a fundamental breakthrough because of the need for anti-aggression and the expansion of Chinese traditional history and academic field. They not only started the basic geographical concept there are four oceans in the five continents in the space, but also to some major Western capitalist countries of the historical development, social history of the concept of time, especially the expansion of the trend and essence of them, have a more thorough understanding. They have realized that this expansion has posed a great threat to China. Due to the influence of dual cultural knowledge structure, Chinese to explore the world of the doctor in the examination process, although the breakthrough of Chinese geographical concepts, formed their own sense of the world, but they did not completely abandon the idea. On the other hand, they can overcome the shortages of the traditional Chinese concept of region outside the ignorant, explore and understand the world.

\subsection{Raise of Science Thought}

The traditional Chinese intellectuals generally have a psychological tendency to despise natural science. Their attention is mostly attracted to the study of humanities, and the research on natural science is rather indifferent. Due to the lack of knowledge of natural science, in the Opium War, although most scholars scholars showed strong anti-aggression spirit, but the end result of the ship old guns blunt, act, and failed to resist the enemy. But after the Opium War, the national crisis and the impact of changes in the structure of knowledge. The intellectuals has changed the traditional kind of extremely indifferent attitude to the knowledge of natural science, instead of showing great interest and strong learning desire. When they introduced the western works and some memorials, letters, diaries, notes, is full of the nature of scientific progress of praise. In addition to the influence of political, economic and cultural aspects, the dissemination of Western learning after the Opium War is also an important condition for China's modern education. The foreign affairs education in the period of the Westernization Movement is the embryonic stage of China's modernization education. It is an important chapter in the history of Chinese education which cannot be erased. There are mainly three aspects of westernization education: Westernization school trains modern talents for China, and 
overseas education sends students to Europe to accept advanced education, to translate western excellent works and disseminates western advanced knowledge. Westernization education is the sprout of modern education. It transforms Chinese education from traditional mode to modernization mode, which is a complete negation of feudal education which has already been unable to meet the requirements of social productivity development in old China. China's modern and modern education has begun. The Western colonialists are making a direct impact on China's sovereignty and territorial integrity by means of advanced science and technology. Therefore, we should use western advanced science and technology to resist Western aggression. The emergence of ideological consciousness attached great importance to the great role of natural science, which was a leaping progress in China.

\subsection{Form of Democracy Concept}

China is a country that is full of revolutionary spirit and loves freedom and equality. Extensive and profound Chinese culture and ideology system also contains rich anti feudal autocratic ancient democratic thoughts, and it is manifested in the form of "emphasizing the people". These works not only the size of coarse introduced western political affairs, including the parliamentary system, the electoral system, the constitutional system, reveals the essential difference between the modern western democratic system and China feudal autocratic system, but when it comes to this, these works with virtually the same words of praise and admiration. However, we should also see that due to the deep influence of Chinese traditional culture and profound Ancient Chinese Literature Search accomplishment explored western political affairs and did not completely copy the theory and model to transform China's social and cultural traditions, but in the nation values as the starting point, focus on people as the center, to choose to Chinese tick, hope that the traditional thought of the people as the basis, learn from western theories and methods, build a suitable China conditions and has China characteristics, independent social and political mode and mode of thinking. That's why they give high evaluations of Western democracy and show strong attachment to China's people-oriented thoughts, which is a true portrayal of their dual psychological structure. To sum up, under the situation of national crisis. They preliminarily carried out the exploration of the reconstruction of modern Chinese cultural system, which had a great influence on the future generations. Western school for the reform movement became an important medium for the spread of Western learning. Although westernization movement is the impact of western culture on Chinese traditional culture, it does not touch the rotten feudal dictatorship, so it is hard for China to embark on the road of prosperity and strength. The Westernization Movement did not learn the essence of western culture and almost failed to achieve the desired results. The political and economic and cultural models of the West were studied by the variant of the law, and Western learning was advocated and the new style of land and sea armament was retrained.

\section{Conclusion}

The outbreak of the Opium War was an epoch-making event, and since then China began to enter modern times. The social situation in China has changed greatly compared with the previous generation. Correspondingly, Chinese traditional culture has also encountered the comprehensive impact of modern western culture. The modernization of Chinese culture requires the incorporation of Chinese culture into the world culture system, making Chinese culture an important part of the world's multicultural patterns.

\section{References}

[1] Yue Feng, Lin Feng. On Jesuits Translation and Dissemination of I Qing Before the First Opium War [J]. Chinese Culture Research, 2016(3): 150-159.

[2] Jin Hongyu. On the Characteristics of Protestant Missionaries' Spreading Western Culture before the Opium War [J]. Journal of Shanxi Radio \& TV University, 2010(4): 94-95. 
[3] Zhu Chunting. East Using West Pruducts and East Meeting West Culture Before Opium War [J]. Journal of Jiangxi Institute of Education (Comprehensive), 2009, 30(3): 76-80.

[4] Zhao Yi, Bu Zhaojing. The international situation of China before the OpiumWar [J]. Journal of Liaoning Normal Universit y Social Science Edition, 2017, 40(2): 138-145. 